\title{
PUBLICIDAD DE AUTOMÓVILES Y RESPETO AL MEDIO AMBIENTE: LAS LIMITACIONES DE LA AUTORREGULACIÓN PUBLICITARIA ${ }^{1}$
} Advertisement for cars and respect the environment: The limitations of advertising self-
regulation

Recibido: 23 de octubre de 2020

Aceptado: 13 de enero de 2021

\author{
Juana María González Moreno \\ Doctora en Derecho \\ Profesora Sustituta Interina \\ Departamento de Derecho Público \\ juanamaria.gonzalez@uca.es \\ Universidad de Cádiz
}

\section{RESUMEN}

El tráfico rodado es responsable en parte de la crisis medioambiental, como volvió a demostrarse con la reducción de la contaminación en las ciudades que produjo el confinamiento decretado en los primeros meses de este 2020 para hacer frente a la pandemia del coronavirus. Sin embargo, a día de hoy los coches han vuelto a tomar las ciudades y las empresas de automoción redoblan sus esfuerzos en publicidad para aumentar las ventas. Una publicidad cuyo control está a manos de un sistema de autorregulación publicitaria que tiene limitaciones, como explicamos en este trabajo, y que, por tanto, habría de ser regulada jurídicamente de forma más amplia.

\section{PALABRAS CLAVE}

publicidad, automóviles, medio ambiente, autorregulación, jurado de la publicidad.

\begin{abstract}
Road traffic is responsible for a part of environmental crisis, as demonstrated again with the decrease of pollution in the cities generated by the lockdown ordered in the first months of 2020 year to fight the COVID-19 pandemic. However, today cars have got back to the street and the motoring enterprises double their efforts in advertising to increase their sales. An advertisement whose control is in the hands of a seftregulation system which has limitations, as we explain in this paper and which, therefore, should be juridically regulated more thoroughly.
\end{abstract}

\section{KEYWORDS}

advertising, cars, environment, self-regulation, advertising's jury.

\footnotetext{
${ }^{1}$ Investigación desarrollada en el marco del Grupo de Investigación SEJ-587 "Economía y fiscalidad frente al envejecimiento poblacional" del Departamento de Derecho Financiero y Filosofía del Derecho de la Universidad de Málaga. Un avance de las ideas aquí expresadas constituyó el contenido de la comunicación presentada en el VI Congreso El tiempo de los derechos, en la línea temática "Responsabilidades públicas y privadas de las empresas en un mundo globalizado" (Universidad de Sevilla, 4 y 5 de noviembre de 2019).
} 
Sumario: 1. Introducción: "lágrimas de cocodrilo". 2. Los escasos límites legales de la publicidad de automóviles. 3. El sistema de autorregulación publicitaria: limitaciones de entrada. 4. Las (discutibles) pautas de actuación del órgano de Autocontrol, el Jurado de la Publicidad. 4.1. La supervisión de las alegaciones sobre consumo de combustible y emisiones de $\mathrm{CO} 2$, centrada en la honestidad de la promesa comercial. 4.2. La laxitud en el control de la "publicidad verde engañosa" cuando no se afecta a la promesa comercial. 4.3. La utilización de criterios meramente formales para determinar si la publicidad incita o alienta comportamientos que perjudican el medio ambiente. 5. A modo de conclusión. 6. Bibliografía y materiales de referencia.

\section{Introducción: "lágrimas de cocodrilo".}

“Lágrimas de cocodrilo" era la expresión que resumía, según Martínez Pisón, la actitud de los países ricos del planeta ante el problema del medio ambiente y del desarrollo en la Cumbre de la Tierra de Río de Janeiro, de 1992, porque los gobernantes de esos países allí reunidos clamaron contra los desastres, propusieron medidas aparentemente contundentes, y luego se olvidaron de todo ello salvo para lanzar reproches a los demás ${ }^{2}$. Pero la falta de autenticidad, la falta de coherencia, que es lo que se quiere denotar cuando se utiliza esa expresión - a costa de los cocodrilos, que realmente no serían tan hipócritas -, sigue siendo la actitud predominante aún hoy, y no sólo en los gobernantes de países ricos, en relación a la problemática medioambiental. Y a la falta de autenticidad y de coherencia puede añadirse la inacción y la adopción de medidas escasamente eficaces para la protección del medio ambiente, como viene denunciando el movimiento mundial de "Jóvenes por el clima"3.

Somos conscientes - exceptuando a los negacionistas - del cambio climático y de la gravedad de sus consecuencias. Pero nos contentamos con alcanzar una cierta cuota de reducción de emisiones de $\mathrm{CO}_{2}$ para frenar el cambio climático ${ }^{4}$ - cuando se necesitarían cambios sustantivos en nuestros modos de vida ${ }^{5}$, y aun así, esto es, aun siendo limitados nuestros compromisos, adoptamos medidas poco acordes con la urgencia climática ${ }^{6}$, o volvemos sobre nuestros pasos, eliminando medidas que serían más protectoras del medio ambiente ${ }^{7}$.

\footnotetext{
${ }^{2}$ Es el comentario que hace MARTÍNEZ PISÓN al libro de N. MIDDLETON, PH. O’KNEEFE Y S. MOYO (1993), Tears of the crocodile. From Rio to reality in the developing world, London, Pluto Press. Vid. MARTÍNEZ PISÓN, J. (2004), "Las generaciones de derechos", en BETEGÓN, J., LAPORTA, F.J., PARAMO, J.R., DE Y PRIETO SANCHÍS, L. (Coords,): Constitución y Derechos Fundamentales, Madrid: Centro de Estudios Políticos y Constitucionales, pp. 409-435, p. 430.

${ }^{3}$ Movimiento que, como ya es conocido, lidera la estudiante sueca Greta Thunberg, quien también se ha referido a la hipocresía de los gestos políticos. Puede leerse: EFE (2019), "Greta Thunberg en Roma: Los líderes me felicitan pero no actúan por el clima”, EFE, 18/4/2019 [En línea]: https:/www.efe.com/efe/espana/gente/gretathunberg-en-roma-los-lideres-me-felicitan-pero-no-actuan-por-el-clima/10007-3955901.

${ }^{4}$ Esta ha sido la pauta adoptada a nivel internacional con el Protocolo de Kyoto al Convenio Marco sobre el Clima de Nueva York, de 1992, renovado en el Acuerdo de París, de 2015, consistente en calcular una cifra de reducción de emisiones, cifra que luego se distribuye entre los Estados miembros según el PIB relativo.

${ }^{5}$ Puede leerse, a título indicativo, lo que manifiesta en este sentido RIECHMANN, J. (2005), "Son necesarios cambios sustantivos", Revista Española de Salud Pública, 2005, vol. 79, pp. 129-131; RIECHMANN, J. (2008), ¿En qué estamos fallando? Cambio social para ecologizar el mundo, e-book, 2008.

${ }^{6}$ Es lo que denunció Ecologistas en Acción en sus observaciones al Anteproyecto de Ley de Cambio Climático y Transición Energética, y al borrador del Plan Nacional Integrado de Energía y Clima (ECOLOGISTAS EN ACCIÓN. (2019), "La respuesta política a la emergencia climática sigue siendo insuficiente", 5/04/2019. [En línea]: https://www.ecologistasenaccion.org/118073/la-respuesta-politica-a-la-emergencia-climatica-siguesiendo-insuficiente/)

${ }^{7}$ Por ejemplo, suprimiendo carriles bici (vid. DOMINGO, M.R., CALLEJA, I.S. (2019), "Almeida inicia la reversión de carriles bici por el de la Gran Vía de Hortaleza”, $A B C, 28 / 10 / 2019$. [En línea]:
} 
Sabemos que los automóviles son uno de los productos más contaminantes, pues lo son tanto en su fabricación como en su funcionamiento, por las emisiones, el ruido y los residuos que generan ${ }^{8}$ (de hecho, la crisis ocasionada por el coronavirus ha demostrado la cuota de responsabilidad que tienen en las emisiones de $\mathrm{CO}_{2}$, ya que el confinamiento tuvo como efecto colateral una reducción de la contaminación en las ciudades ${ }^{9}$ ). Y sabemos también que los automóviles considerados "ecológicos" también contaminan: desde hace ya más de diez años, asociaciones de consumidores y ecologistas, sobre todo, vienen insistiendo en que el coche híbrido es contaminante porque sigue utilizando gasolina y baterías para generar el motor eléctrico, así como por los elementos residuales que genera durante y al final de su vida útil ${ }^{10}$; y vienen insistiendo también en que tampoco son ecológicos los coches eléctricos, que hoy se anuncian como la panacea para resolver el cambio climático, porque si bien estos coches no producen emisiones de $\mathrm{CO}_{2}$ en su conducción (y por eso se publicitan como los más ventajosos en términos de impuesto de matriculación) sí producen emisiones en el lugar de la producción de energía, y lo que cuenta para reducir el cambio climático son las cantidades totales de $\mathrm{CO}_{2}$ emitidas $^{11}$.

Efectos contaminantes (los de los automóviles) que, por cierto, no sólo afectan (en forma difusa) al medio ambiente sino a la vida humana, como se ha puesto de manifiesto en la crisis del coronavirus, al señalarse el vínculo que existe entre contaminación del aire y el pronóstico (recuperación o no) del coronavirus ${ }^{12}$. Aparte de que no debemos olvidar la afectación directa

https://www.abc.es/espana/madrid/abci-almeida-inicia-reversion-carriles-bici-gran-hortaleza-
201910280125_noticia.html Una medida con escaso sentido teniendo en cuenta los graves problemas de
contaminación experimentados en ciudades como Madrid y Barcelona, problemas originados en gran parte por
el tráfico rodado y que han motivado que la Comisión Europea se plantee denunciar a España por los
incumplimientos reiterados de la normativa sobre calidad del aire. Con más detalle sobre este punto, puede leerse:
DE MIGUEL, B., PLANELLES, M. (2019), "Bruselas lleva a España ante la justicia por la contaminación en
Madrid y Barcelona", Bruselas/Madrid, El País, 24/6/2019. [En línea]: https://elpais.com/sociedad/2019/07/23/actualidad/1563894873_941133.html

8 Sobre el impacto de los automóviles en la calidad del aire, en el aumento del efecto invernadero, vid. ASOCIACIÓN GLOBALÍZATE. (2005), “Automóviles y publicidad”, pp. 4-7. [En línea]: http://www.globalizate.org; UNIÓN DE CONSUMIDORES DE ESPAÑA, UCE (ed.). (2008), Informe publicidad medio ambiente, p. 22; ANDALUZ, J. Y ESTEBAN, A. (2015), "Emisiones en España: alimentación, transporte", Ecologista, n ${ }^{\circ} 86$, pp. 25-26, p. 25.

${ }^{9}$ FERNÁNDEZ CARRASCO, A. (2020), “Así ha bajado la contaminación durante el estado de alarma por el coronavirus", 19/03/2020. [En línea]: https://es.greenpeace.org/es/noticias/asi-ha-bajado-la-contaminaciondurante-el-estado-de-alarma-por-el-coronavirus/. REDACCIÓN DE NATIONAL GEOGRAPHIC ESPAÑA (2020), "El coronavirus reduce la contaminación del aire”, National geographic España, 24/04/2020. [En línea]: https://www.nationalgeographic.com.es/ciencia/coronavirus-reduce-contanimacion-aire-europa_15370

10 Vid. UNIÓN DE CONSUMIDORES DE ESPAÑA, UCE (ed.). (2008), Informe publicidad medio ambiente, p. 22; ECOLOGISTAS EN ACCIÓN. (2009), "Coche ecológico/emisiones de CO2 de los vehículos convencionales e híbridos". 1/12/2009. [En línea]: https://www.ecologistasenaccion.org/16233/2-emisiones-deco2-de-los-vehiculos-convencionales-e-hibridos/

${ }^{11}$ Puede leerse lo escrito por redacción de La Vanguardia en febrero de este año: "Ecologistas defiende que coche eléctrico genera "un gran impacto ambiental", La Vanguardia, 28/02/2020. [En línea]: https://www.lavanguardia.com/vida/20200228/473824252974/ecologistas-defiende-que-coche-electricogenera-un-gran-impacto-ambiental.html. Asimismo, puede verse lo expresado por NÚÑEZ CANSADO, M.; RODRIGO MARTÍN, L. (2015), “Autorregulación y creatividad publicitaria en el sector del automóvil en España: freno al tren verde", Revista de Comunicación Vivat Academia, septiembre 2015, Año XVIII, n 132 , pp. 38-87, p. 50; BRAU, L. (2018), "La ciudad del coche”. Biblio3W. Revista Bibliográfica de Geografía y Ciencias Sociales, vol. XXIII, no 1235, Barcelona: Universidad de Barcelona, 5 de mayo de 2018, pp. 1-27. [En línea]: http://www.ub.edu/geocrit/b3w-1235.pdf. BERMÚDEZ, J.J. (2009), "La ideología del coche eléctrico", Canarias Ahora, 14/08/2008. [En línea]: https://www.eldiario.es/canariasahora/canariasopina/ideologia-cocheelectrico_6_292630774.html.

${ }^{12}$ Vid. ELCACHO, J., "La OMS reitera que la contaminación del aire empeora el pronóstico de la Covid-19", La Vanguardia, 07/09/2020. [En línea]: 
a la vida y a la salud que los automóviles provocan o, para decirlo más claro, las cifras de personas muertas o con lesiones graves a raíz de accidentes automovilísticos, cifras en las que últimamente se repara poco ${ }^{13}$.

Por último (que no para terminar con la problemática), sabemos del impacto que tiene la publicidad sobre las ventas, particularmente en el caso de los automóviles, el "objeto más anunciado del mundo (...)"14; y que esta publicidad, que no cesa ni en tiempos de crisis (tampoco con la del coronavirus ${ }^{15}$ ), no tiene por costumbre advertir de los efectos nocivos del producto publicitado (los automóviles) - cosa que debería hacer, como ha expresado algún autor $^{16}$, a semejanza con lo que ya se hace con la publicidad de otros productos como tabaco, bebidas alcohólicas, alimentación -, sino que más bien hace lo contrario: camufla las repercusiones del producto (automóvil) en cuestión, entre ellas las repercusiones medioambientales ${ }^{17} \mathrm{y} / \mathrm{o}$ hace gala de un discurso supuestamente ecológico que no tiene correspondencia con la realidad, incurriendo las más de las veces en lo que se da en llamar "publicidad verde engañosa". En definitiva, que se emiten mensajes no veraces o mensajes inexactos que pueden inducir a error a los consumidores sobre el supuesto carácter ecológico (o "cero emisiones") del automóvil, y propiciar un mayor uso del mismo ${ }^{18}$, con lo cual el impacto sobre el medio ambiente no se reduce, se mantiene e incluso puede aumentar ${ }^{19}$.

https://www.lavanguardia.com/natural/contaminacion/20200907/483347888356/la-oms-reitera-que-lacontaminacion-del-aire-empeora-el-pronostico-de-la-covid-19.html

${ }^{13}$ Entre las escasas referencias al tema, vid. TAPIA GRANADOS, J.A. (1998), "La reducción del tráfico de automóviles: una política urgente de promoción de la salud”, Revista Panamericana de Salud Pública/ Pan Am J Public Health, 3 (3), pp. 137-151.

${ }^{14}$ Vid. BRAU, L. (2018), "La ciudad del coche", op. cit., pp. 17, 16.

${ }^{15}$ Al igual que ha ocurrido en otras crisis - por ejemplo, en la Guerra del Golfo, vid. MARTÍN, E. (1991), "Mercado en punto muerto: A pesar de la recesión, los fabricantes de automóviles de turismo destinaron en 1990 un 12, 9 \% más a publicidad que en 1989”, Anuncios: Semanario de publicidad y marketing, no 467, 25 de marzo de 1991, pp. 32-33 -, la caída en las ventas de automóviles con la crisis del coronavirus no se ha traducido en una disminución de la publicidad. Por otro lado, esa caída en las ventas es relativa: el sector de automoción reconoce que durante el confinamiento los consumidores fueron especialmente receptivos a anuncios de coches eléctricos, sobre todo al ver los beneficios medioambientales que ha tenido el confinamiento y la reducción de la circulación, lo que es posible que les lleve a adoptar decisiones de compras en el futuro esa dirección (vid. FERNÁNDEZ, S. (2020), "Automoción despierta su publicidad para luchar contra la crisis del Covid-19", 18/08/2020. [En línea] https://www.elpublicista.es/reportajes/automocion-despierta-publicidad-para-lucharcontra-crisis-covid).

${ }^{16}$ Así, según Pedrós Pérez, los fabricantes de automóviles deberían incluir en su publicidad mensajes explícitos del tipo "las emisiones de este vehículo son contaminantes y contribuyen al efecto invernadero" o, "en ciudad, utiliza el transporte público" (PEDRÓS PÉREZ, G. (2007), Hacia una publicidad responsable frente al cambio climático. Borrador para el debate. Centro Nacional de Educación Ambiental, CENEAM, Oficina Española de Cambio Climático, OECC, 2007, pp. 1-28, p. 1).

${ }^{17}$ Que no se reducen a las emisiones de CO2. Hay otra serie de daños, como la contaminación del aire, la contaminación acústica o la ocupación del espacio público, entre otros, que ya fueron puestos de manifiesto en los años 70. Vid. GORZ, A. (1973), "La ideología social del automóvil”, Letras libres, 11, Núm. 132, 2009 , pp. 14-17 [En línea] https://www.letraslibres.com/mexico-espana/la-ideologia-social-del-automovil; GALEANO, E. (sin fecha), La religión del automóvil, La religión del automóvil. Servicios de Comunicación Intercultural, p. 2. [En línea] https://www.servindi.org/actualidad/1427

${ }^{18}$ UNIÓN DE CONSUMIDORES DE ESPAÑA, UCE (ed.). (2008), Informe publicidad medio ambiente, op. cit., pp. 19, 22.

${ }^{19}$ Es lo que habría pasado con el conocido "escándalo de Volskwagen”, que explicaría en parte cómo aún a pesar de la crisis - factor que supone una reducción en las magnitudes del transporte -, no hubo reducción significativa en los niveles de dióxido de carbono en las ciudades (ANDALUZ, J. Y ESTEBAN, A. (2015), "Emisiones en España: alimentación, transporte", op. cit., p. 25). Puede leerse también: MARTÍN- SOSA, S.; GARCÍA, M.; GONZÁLEZ, M. (2015/2016), "Engaños de la industria automovilística. Caso Volkswagen: la punta del iceberg de un sistema fraudulento", Ecologista, no 87, 2015/2016, pp. 32-33. 
Y a la "publicidad verde engañosa" se suman otras demostraciones del poco respeto hacia el medio ambiente como el no hacer referencias directas o indirectas a la protección del medio ambiente en los anuncios publicitarios ${ }^{20} \mathrm{o}$, lo que es más perjudicial, representar al automóvil (privado, fundamentalmente) en situaciones poco propicias para dicha protección, en espacios no preparados para él o incluso en paisajes naturales conservados, o "protagonizando" conductas no respetuosas con el medio ambiente en espacios naturales; o también, representar al automóvil en contextos de uso poco sostenible (por ejemplo, llevando a un/a solo/a ocupante $)^{21}$. Representaciones que no son inofensivas: en cuanto tales, en cuanto representaciones, producen una normalización de las conductas en cuestión y, en consecuencia, propician su reproducción. Lo que ha motivado que en algún país como Francia se haya llegado a sancionar a empresas automovilísticas por abusar de ese tipo de representaciones ${ }^{22}$.

Sin embargo, repetimos la idea, pese a todo lo que sabemos - esto es, las consecuencias que, en general, se siguen de atentar contra el medio ambiente, tanto para éste mismo como para la vida humana, así como las diversas y concretas formas en que la publicidad de automóviles puede afectar al medio ambiente - son escasos los límites legales establecidos a esta publicidad, y el control de la misma está confiado a un sistema de autorregulación publicitaria que presenta a su vez una serie de limitaciones. Es lo que pretendemos demostrar en este trabajo, concentrándonos para ello en el análisis de la legislación nacional y europea sobre comunicaciones comerciales que contiene algunas disposiciones sobre la publicidad de automóviles, así como de las normas que integran el sistema de autorregulación publicitaria, y de las resoluciones dictadas por el órgano de supervisión de dicho sistema, el Jurado de la Publicidad. La bibliografía sobre esta temática sigue siendo todavía muy escasa, y por eso, como podrá apreciarse, hemos tenido que recurrir a documentos de asociaciones de consumidores y ecologistas, y a artículos publicados en la prensa para ilustrar distintos aspectos de la publicidad de automóviles.

\section{Los escasos límites legales de la publicidad de automóviles.}

La defensa y respeto el medio ambiente por parte de los poderes públicos tiene la entidad de principio rector de la política social y económica en nuestra Constitución ${ }^{23}$, pero las leyes sobre comunicaciones comerciales no se han hecho eco de este principio o lo han hecho en forma limitada. Así, la Ley 34/1988, de 11 de noviembre, General de Publicidad (en su último texto consolidado de 28 de marzo de 2014), no contiene ninguna disposición expresa en relación al medio ambiente.

\footnotetext{
${ }^{20}$ Vid. RUIZ PACHECO, C.; CONDE GUERRI, M.E. (2002), "El uso del medio ambiente en la publicidad", Medio Ambiente y Comportamiento Humano, 3 (1), pp. 89-101; ASOCIACIÓN GLOBALÍZATE, “Automóviles y publicidad", op. cit.

21 Entre los estudios ya realizados sobre esta cuestión, vid. ASOCIACIÓN GLOBALÍZATE. (2005), “Automóviles y publicidad”, op. cit.; LÓPEZ PASTOR, A.T., DE ANDRÉS DEL CAMPO, S., Y GONZÁLEZ MARTÍN, R. (2007). Tratamiento del medio ambiente en la publicidad convencional (2006-2007), Resumen de Informe, Ministerio de Medio Ambiente y medio rural y marino, Universidad de Valladolid, pp. 28-29, p. 29; HERAS HERNÁNDEZ, F. (2012). "El uso de argumentos ambientales en publicidad. Definiendo líneas rojas, reconociendo buenas prácticas", Boletín Carpeta Informativa del Centro Nacional de Educación Ambiental. CENEAM, O.A. Parques Nacionales, pp. 1-7; AGUILAR OLMEDO, A. (2018), El medio ambiente en la publicidad. Análisis desde la ética de las virtudes. Trabajo de Fin de Grado (inédito), curso académico 2018-19, Jerez de la Frontera: Facultad de Ciencias Sociales y de la Comunicación, Universidad de Cádiz.

${ }^{22}$ Concretamente, a Toyota. Vid. CHEVALIER, J., "Quand une voiture dans la nature offense le regard du juge", Le Point Automobile, 23/10/2012. [En línea] https://www.lepoint.fr/automobile/quand-une-voiture-dans-lanature-offense-le-regard-du-juge-23-10-2012-1520221_646.php

${ }^{23}$ Concretamente, en el artículo 45.
} 
Ha sido la Ley 7/2010, de 31 de marzo, General de la Comunicación Audiovisual la que ha establecido expresamente en su artículo 18, 4 la prohibición de comunicaciones comerciales que fomenten comportamientos nocivos contra el medio ambiente ${ }^{24}$. No obstante, como se desprende del propio tenor de esta Ley, la prohibición citada no alcanza a las comunicaciones comerciales que se realicen por medios diferentes a los audiovisuales. Por otra parte, por lo que respecta a las comunicaciones comerciales audiovisuales, que sí caen en su órbita, dada la generalidad de los términos con que se enuncia la prohibición en el artículo 18, 4 de la Ley podrían entenderse abarcados buen número de anuncios de televisión e internet no respetuosos del medio ambiente - incluso hasta podría incluirse en el mismo la publicidad de productos que de alguna manera son contaminantes o también de productos para cuya producción se produce contaminación, como sería el caso de los automóviles -. Pero el hecho es que la prohibición citada es inaplicada en la práctica: la publicidad de automóviles productos contaminantes tanto en su fabricación como en su funcionamiento - sigue existiendo. De ahí que dada esta contradicción haya quien considere que la prohibición de comunicaciones comerciales que fomenten comportamientos nocivos para el medio ambiente contenida en la Ley de Comunicación Audiovisual es más bien puro marketing legislativo que una norma que realmente se pueda aplicar ${ }^{25}$.

Más precisa es la obligación (de los fabricantes e importadores de automóviles, aunque la Ley no los designe expresamente como sujetos obligados ${ }^{26}$ ) de facilitar al/la consumidor/a información sobre sobre el consumo de combustible y sobre las emisiones de $\mathrm{CO}_{2}$ al comercializar turismos nuevos que se pongan a la venta o se ofrezcan en arrendamiento financiero en territorio español. Esta obligación se contiene en el Real Decreto 837/2002, de 2 de agosto, por el que se regula la información relativa al consumo de combustible y a las emisiones de $\mathrm{CO}_{2}$ de los turismos nuevos que se pongan a la venta o se ofrezcan en arrendamiento financiero en territorio español, Real Decreto que se dictó para aplicar en España una directiva europea ${ }^{27}$, parte a su vez de parte de la política ambiental de la Unión Europea, derivada de los compromisos adquiridos por la Unión Europea en base al Protocolo de Kyoto al Convenio Marco de las Naciones Unidas sobre el Cambio Climático, adoptado en Nueva York, en $1992^{28}$.

En el Real Decreto mencionado se dispone, en concreto en su artículo 7 que los impresos de promoción (cuyo concepto también lo precisa el Real Decreto ${ }^{29}$ ) deberán incluir (so pena

\footnotetext{
${ }^{24}$ En su artículo 18, 4 incluye expresamente entre las comunicaciones comerciales prohibidas en cualquiera de sus formas, "la comunicación comercial que fomente comportamientos nocivos para el medio ambiente".

${ }^{25}$ LASHERAS, J. (2016), "La prohibición de la publicidad contraria al medio ambiente”, Observatorio Jurídico de la Publicidad, 12/6/2016. [En línea]: http://observatoriojuridicodelapublicidad.com/la-prohibicion-de-lapublicidad-contraria-al-medio-ambiente/

${ }^{26}$ No hay en el Real Decreto 837/2002 un precepto que concrete los sujetos obligados, pero por sentido común y por las alusiones que en el cuerpo del Real Decreto se hacen a fabricantes e importadores de automóviles, hay que interpretar que la obligación de facilitar información que se regula en el mismo la tienen estos sujetos.

${ }^{27}$ La Directiva 1999/94/CE, de 13 de diciembre, del Parlamento Europeo y el Consejo, relativa a la información sobre el consumo de combustible y sobre las emisiones de $\mathrm{CO} 2$ facilitada al consumidor al comercializar turismos nuevos.

${ }^{28}$ Efectivamente, la firma por la Unión Europea del Protocolo de Kyoto llevó a la elaboración de una Política Climática Comunitaria que se ha traducido en normas vinculantes (directivas y reglamentos) para los Estados miembros, como fue el caso también de la Directiva 98/69/CE, del Parlamento Europeo y del Consejo de 13 de octubre de 1998 relativa a las medidas que deben adoptarse contra la contaminación atmosférica causada por las emisiones de los vehículos de motor y por la que se modifica la Directiva 70/220/CEE del Consejo (en forma abreviada, directiva Euro V, diseñada para la industria de la automoción, con el fin de reducir las emisiones de $\mathrm{CO} 2)$.

${ }^{29}$ Según su artículo 7 del Real Decreto 837/2002 vienen a ser el conjunto de impresos utilizados para la comercialización, publicidad y promoción de vehículos entre el público en general, un concepto que abarca, como mínimo, los manuales técnicos, los folletos, los anuncios en periódicos, las revistas, la prensa especializada
} 
de incurrir en infracciones y sanciones según dice su artículo 10) los datos oficiales sobre consumo de combustible y específicos sobre emisiones de $\mathrm{CO}_{2}$ relativos a los mismos, de acuerdo con los requisitos fijados en el anexo IV. Requisitos entre los que están, entre otros, el ser de fácil lectura, visibilidad, fácil comprensión, así como el suministrar los datos relativos al consumo oficial de combustible de todos los modelos del vehículo a los que se refieran los impresos de promoción. Y, ciertamente, la obligación establecida no es baladí. Como puede leerse en el Preámbulo del Real Decreto 837/2002, la inclusión de información relativa al consumo de combustible y a las emisiones de $\mathrm{CO}_{2}$ es importante porque incide en el comportamiento de las fuerzas de mercado: influye en la decisión del consumidor a favor de los automóviles que consuman menos combustible y por lo tanto emitan menos $\mathrm{CO}_{2}$, impulsando de este modo a los fabricantes a hacer lo necesario para reducir el consumo de los mismos. Por otra parte, la inclusión de dicha información es considerada como un derecho de los consumidores y usuarios ${ }^{30}$.

Ahora bien, afinando el análisis puede percibirse que la obligación de información sobre el consumo de combustible y la emisión de $\mathrm{CO}_{2}$, al comercializar turismos nuevos que se pongan a la venta o se ofrezcan en arrendamiento financiero en territorio español contenida en el Real Decreto 837/2002 está pensada en primera instancia como una forma de proteger a los consumidores de los productos, los automóviles, más que en el medio ambiente, como se repite en el artículo 1 del Real Derecho a la hora de concretar el objeto del propio Real Decreto $^{31}$. Consumidores a los que en último término se está remitiendo muy sutilmente la responsabilidad por las emisiones (y, en definitiva, por el no respeto del medio ambiente), si deciden comprarse un vehículo contaminante, y no a los fabricantes ni a los vendedores de automóviles (contaminantes). De hecho, como se expresa en el texto del Real Decreto 837/2002, las infracciones de los preceptos contenidos en el Real Decreto se consideran infracciones en materia de protección al consumidor, de acuerdo con lo establecido en el artículo 34 de la Ley 26/1984, de 14 de julio, General de Defensa de los Consumidores y Usuarios y con los artículos 3 y 5 del Real Decreto 1945/1983, de 22 de junio, que regula las infracciones y sanciones en materia de consumidor $\mathrm{o}$ en la correspondiente norma autonómica ${ }^{32}$.

Como colofón, en el Real Decreto en cuestión, el alcance de la obligación prevista es limitado. Para la publicidad comercial que se emite en televisión o en internet, la más visualizada en nuestros días, no hay disposición expresa, aunque pueda incardinarse, vía interpretación, en el artículo 7 del Real Decreto, en el que se concretan cuáles son los impresos de promoción "como mínimo". Y, en todo caso, no hay que perder de vista que la obligación de indicar el consumo de combustible y la emisión de $\mathrm{CO}_{2}$ resulta insuficiente para la

\footnotetext{
y los carteles deben incluirla. Y los requisitos que debe reunir la información sobre los datos de consumo oficial de combustible y de las emisiones específicas de CO2 de los vehículos se detallan en el Anexo IV del Real Decreto.

${ }^{30}$ En el Preámbulo del Real Decreto 837/2002 se hace referencia a que la Ley 26/1984, de 19 de julio, General para la Defensa de los Consumidores y Usuarios, establece en su artículo 2.1. como un derecho básico de los consumidores y usuarios la información correcta sobre los diferentes servicios, para facilitar el conocimiento sobre su adecuado uso y disfrute, y también a que este derecho a la información de los consumidores y usuarios ha sido desarrollado en nuestra legislación mediante diversas disposiciones, entre otras, el Real Decreto 1468/1988, de 2 de diciembre, por el que se aprueba el Reglamento de etiquetado, presentación y publicidad de los productos industriales destinados a la venta directa a los consumidores y usuarios (vid. Real Decreto 837/2002, Preámbulo, segundo y tercer párrafo).

${ }^{31}$ Literalmente: “Artículo 1. Ámbito de aplicación. El presente Real Decreto tiene por objeto garantizar que se proporcione a los consumidores información relativa al consumo de combustible y a las emisiones de $\mathrm{CO} 2$ de los turismos nuevos que se pongan a la venta o se ofrezcan en arrendamiento financiero en territorio español, para que los consumidores puedan elegir con fundamento".

${ }^{32}$ Vid. el artículo 10 del Real Decreto 837/2002 ya citado.
} 
protección del medio ambiente ante la diversidad de formas en que la publicidad (de automóviles) puede afectar al mismo ${ }^{33}$, entre las que están la extensa gama de variantes que puede revestir la "publicidad verde engañosa", y también la representación de "conductas no respetuosas del medio ambiente".

\section{El sistema de autorregulación publicitaria: limitaciones de entrada.}

El control de la publicidad de automóviles lo realiza fundamentalmente el sistema de autorregulación publicitaria, un sistema establecido, para toda la publicidad comercial, en general, por los propios profesionales del sector. Este sistema, que es el que impera prácticamente en todos los países, en España es gestionado por la asociación Autocontrol, creada en 1995 por los principales anunciantes, medios de comunicación, agencias de publicidad y asociaciones empresariales. Esta asociación ha elaborado un código de comunicación publicitaria, en el que se contienen límites a las conductas (en este caso publicitarias) en base a una serie de principios, el Código de Conducta Publicitaria, de 1996, y modificado en $2011^{34}$ (en adelante, CCP), y ha diseñado también órganos de control como el Gabinete Técnico y el Jurado de la Publicidad.

Por lo que se refiere al tema del medio ambiente puede decirse que, al menos en teoría, ha sido un tema abordado por Autocontrol en sus normas (deontológicas, en apariencia). Así, en el CCP, además de enunciarse determinados principios, entre los que están el respeto de la legalidad (norma 2), se contempla expresamente el respeto al medio ambiente como un límite a la publicidad comercial (norma 12) 35 $^{35}$ y el Código de Autorregulación sobre Argumentos Ambientales en Comunicaciones Comerciales, en vigor desde 2009, habría venido a completar la norma 12. En este segundo Código se han fijado - exactamente en el ámbito de la responsabilidad social de la empresa ${ }^{36}$-, una serie de exigencias a los argumentos medioambientales entre las que está el respeto de los principios de legalidad, veracidad, lealtad y responsabilidad y, expresamente, se señala en el mismo, como otra norma comprendida dentro también del ámbito de la responsabilidad social de la empresa que "Las comunicaciones comerciales no deberán mostrar comportamientos perjudiciales para el medio ambiente, a no ser que su exhibición tenga un motivo educativo o demostrativo proambiental, ni deberán incitar a llevar a cabo tales comportamientos"37. Y puede apreciarse asimismo el acento que este Código ha puesto en la "publicidad verde engañosa" ${ }^{38}$.

\footnotetext{
33 Sobre la diversidad de formas en que no se tiene en cuenta el medio ambiente, puede verse: HERAS HERNÁNDEZ, F. (2012). "El uso de argumentos ambientales en publicidad. Definiendo líneas rojas, reconociendo buenas prácticas", op.cit.

34 AUTOCONTROL. (1996), Código de Conducta Publicitaria [En línea] https://www.autocontrol.es/wpcontent/uploads/2017/12/codigo-de-conducta-publicitaria-autocontrol.pdf

${ }^{35}$ En el CCP, la norma 12 dice literalmente así: "Respeto al medio ambiente. La publicidad no incitará ni alentará comportamientos que perjudiquen el medio ambiente".

${ }^{36}$ En este Código puede leerse: "Normas éticas. III. Principio de responsabilidad social. 3. Las comunicaciones comerciales que contengan argumentos ambientales deberán ser hechas con sentido de la responsabilidad social, en los términos en que este concepto se desarrolla en el artículo 4 del Código de Publicidad Comercial y Mercadotecnia de la Cámara de Comercio Internacional (CCI)".

37 Vid. Código de Autorregulación sobre Argumentos Ambientales en Comunicaciones Comerciales, Normas éticas. III. Principio de responsabilidad social. 4.

${ }^{38}$ Así en su apartado IV-. Principio de veracidad, hay que prestar atención a las normas 5, 6 y 7 (en especial, a esta última, que se refiere a que los argumentos ambientales estén basados en pruebas generalmente admitidas...y deben ser verificables...), y a la norma 11, que indica que las aseveraciones genéricas o no específicas sobre beneficios de tipo ambiental, en particular aseveraciones tales como "no dañino para el medio ambiente", "verde", "ecológico", "sostenible", deben evitarse o justificarse mediante acotaciones. Las anotaciones deben ser claras, notorias y fácilmente entendibles, deben encontrarse cerca de la aseveración acotada para asegurar que se lean de forma conjunta".
} 
En cuanto a los órganos de (auto) control de la publicidad comercial, el Gabinete Técnico es un órgano que emite informes de asesoramiento (o Copy Advice) sobre la corrección ética y legal de las campañas publicitarias a los anunciantes, agencias, medios de comunicación que lo soliciten antes de la emisión de la campaña. Informes que son confidenciales, y no vinculantes, por regla general (el solicitante del informe, después de recibirlo, asume la responsabilidad de la emisión o no del anuncio publicitario). Y es sobre todo el Jurado de la Publicidad el que desempeña un papel clave en el sistema de autorregulación publicitaria al ser el órgano encargado de resolver las reclamaciones que se presentan contra los anuncios publicitarios por parte de organismos de las Administraciones Públicas, de particulares, de asociaciones de consumidores, empresas y asociaciones empresariales. Para ello, el Jurado hace una valoración de la corrección o incorrección (ética) de los anuncios conforme al CCP y la legalidad vigente, y al término de su valoración puede emitir o bien una resolución en que expresa si se ha infringido alguna norma deontológica y, en consecuencia, se solicita la modificación o el cese de las campañas, resolución que es vinculante cuando los agentes implicados se han adherido al sistema (de autorregulación publicitaria), o bien un dictamen no vinculante en el caso de comunicaciones comerciales realizadas por terceros no vinculados ${ }^{39}$.

No obstante, este sistema de autorregulación publicitaria tiene limitaciones. La principal, de entrada, es que el sistema se fundamenta enteramente en la autonomía de la voluntad de empresas anunciantes, agencias y medios, los cuales pueden cumplir o no los compromisos voluntariamente acordados (concretamente, las normas contenidas en los códigos de conducta que ellos mismos han elaborado), y pueden decidir someterse o no al órgano de control establecido en el sistema, el Jurado de la Publicidad. La autonomía de la voluntad es, por tanto, el punto fuerte del sistema y al mismo tiempo su "talón de Aquiles", y ello tanto en lo que respecta a las comunicaciones comerciales, en general, como a los anuncios publicitarios de automóviles, en particular ámbito en que prácticamente en todos los países se ha puesto de manifiesto que las empresas anunciantes no cumplen las normas establecidas en los códigos de autorregulación publicitaria, precisamente porque no son vinculantes ${ }^{40}$.

Con todo, y a pesar de estas limitaciones "congénitas" del sistema, en España las resoluciones del Jurado de la Publicidad han creado un cuerpo de doctrina deontológica importante en el que se definen los límites y perfiles de la licitud ${ }^{41}$, un cuerpo de doctrina sustentado en su propia fuerza moral, de la que alardea el Jurado de la Publicidad ${ }^{42}$. Pero, y

\footnotetext{
${ }^{39}$ Sobre el funcionamiento de la autorregulación publicitaria puede verse con más detalle: MEGÍAS QUIRÓS, J. J. Y CABRERA CARO, L. (2013). Ética y Derecho en la Publicidad. Granada: Comares, en concreto, el tema 3. Autorregulación y corregulación en publicidad, pp. 31-43.

40 Vid. DONOVAN, R.J., FIELDER, L.J., OUSCHAN, R., EWING, M., "Self-regulation of motor vehicle advertising: Is it working in Australia?", Accident Analysis \& Prevention, vol. 43, Issue 3, May 2011, pp. 631636; DONOVAN, R.J., FIELDER, L.J., EWING, M.; OUSCHAN, R., "Regulation of motor vehicle advertising: Toward a framework for compliance research", Journal of the Australasian College of Road Safety, vol. 22, Issue 4, Dec 2011, pp. 73-81.

${ }^{41}$ Un cuerpo de doctrina que suele ser utilizado por los órganos jurisdiccionales a la hora de construir el razonamiento lógico que fundamenta sus fallos en materia publicitaria. Vid. RAMOS FERNÁNDEZ, L.F. (2001), "Autorregulación, mediación y consulta previa, la nueva frontera de la ética publicitaria", Zer: Revista de estudios de comunicación, $\mathrm{n}^{\mathrm{o}}$ 11, pp. 1-11, p. 2.

42 Prácticamente en todas sus resoluciones, no sólo en las que tienen que ver con el respeto al medio ambiente, suele incluir el "estribillo" siguiente: "En todo caso, no puede desconocerse que la mayor parte de las resoluciones que emite este Jurado son cumplidas de forma voluntaria incluso por aquellas empresas que no tienen la condición de asociadas al sistema. Probablemente este hecho se explique por la reconocida fuerza moral de que gozan tales resoluciones. Esta fuerza moral se derivaría del acreditado y reconocido prestigio de los miembros del Jurado, y del respaldo legal otorgado al sistema de autodisciplina o autocontrol..." (Resolución de la Sección Quinta del Jurado de 3 de diciembre de 2015, Particular vs. Volvo Car España S.L.U., "Volvo XC60", II. Fundamentos deontológicos. 1., tercer párrafo).
} 
aquí viene otra fuente de limitaciones del sistema de autorregulación publicitaria, la interpretación y aplicación de las normas de los códigos de conducta por parte del propio Jurado de la Publicidad no siempre es loable. Particularmente y por lo que se refiere a la protección del medio ambiente, esta interpretación y aplicación merece algunos reparos.

\section{Las (discutibles) pautas de actuación del órgano de Autocontrol, el Jurado de la Publicidad.}

\subsection{La supervisión de las alegaciones sobre consumo de combustible y emisiones de CO2, centrada en la honestidad de la promesa comercial.}

Uno de los principios contenidos en el CCP es el principio de respeto de la legalidad. Una legalidad que, en el caso de la publicidad de automóviles, como hemos expresado más arriba, es reducida, y que, además, frecuentemente es incumplida. Así, por lo que se refiere a la obligación legal de indicar el consumo de combustible y la emisión de $\mathrm{CO}_{2}$, establecida en 2002 , aunque ya en los anuncios publicitarios no se omite dicha información ${ }^{43}$, las alegaciones al respecto figuran en letra demasiado pequeña y se les imprime una velocidad tal que impide su lectura ${ }^{44}$. Y ello a pesar de que el Jurado de la Publicidad ha insistido, en las reclamaciones presentadas en relación a algunos anuncios publicitarios ${ }^{45}$, en que la información sobre consumo de combustible y emisiones de $\mathrm{CO}_{2}$ de los vehículos es un dato esencial para valorar un modelo, de manera que, en los casos en que tales alegaciones son ilegibles y pasan a velocidad que hace imposible su lectura, se vulnera el CCP, en concreto, su norma $3^{46}$.

La doctrina del Jurado de la Publicidad en torno a esta norma 3 del CCP es doctrina consolidada. Los anuncios u otras expresiones publicitarias deben ser analizados desde la perspectiva de la impresión global que el mensaje genere en el público al que se dirige o alcanza, y los anunciantes deberán tener presente cómo son percibidos sus mensajes por el público, hacer todo lo posible para que todos los mensajes incluidos y que contengan información relativa a la oferta publicitaria sean claramente perceptibles y legibles para un consumidor medio.

Sin embargo, respecto a esta doctrina del Jurado de la Publicidad cabría hacer dos observaciones. La primera, que por más que la misma esté consolidada - y, por consiguiente, claramente marcado el límite a la publicidad comercial - no por ello es más respetada por los

\footnotetext{
${ }^{43}$ PEDRÓS PÉREZ, G. (2007), Hacia una publicidad responsable frente al cambio climático. Borrador para el debate, op.cit.

${ }^{44}$ Los estudios realizados sobre publicidad medioambiental insisten en que las alegaciones sobre emisiones son ilegibles e incluso puede ocurrir que, aunque estas alegaciones (ilegibles) sobre consumo y emisiones figuren en el anuncio en televisión, se prescinda de las mismas en el mismo anuncio transmitido en internet (vid. sobre esto último, AGUILAR OLMEDO, A. (2018), El medio ambiente en la publicidad. Análisis desde la ética de las virtudes, op. cit., pp. 16, 17).

45 Así las reclamaciones contra Honda, Suzuki, General Motors, Hyundai. Véase la Resolución de la Sección Primera del Jurado de 2 de junio de 2011, AUC vs. Honda Automóviles España, S.A., "Honda Civic"; la Resolución de la Sección Quinta del Jurado de 30 de junio de 2011, AUC vs. General Motors España, S.L., "Opel Corsa", y de manera concreta, la Resolución de la Sección Sexta del Jurado de 16 de febrero de 2012, Amigos de la Tierra vs. Hyundai Motor España, S.L.U., "Hyundai IX35" (Fundamentos deontológicos 2 y 3 ).

${ }^{46}$ El párrafo 1 de esta norma 3 se refiere a la necesidad de analizar los anuncios y expresiones publicitarias en su conjunto y atendiendo a la impresión global que generen en sus destinatarios; y el párrafo 2, a que pueden ser objeto de análisis específico las partes de los anuncios que aparecen de forma especialmente destacada, apartado que viene a contener una excepción respecto a la pauta interpretativa general, establecida en el párrafo 1 . Y en el párrafo 3 de la norma 3 se expresa que: "En todo caso, cuando un anuncio contenga un mensaje claramente destacado en el sentido del párrafo anterior, el anunciante deber adoptar las medidas necesarias para que las restantes partes del anuncio sean claramente comprensibles y no introduzcan ni modificaciones ni limitaciones relevantes del mensaje principal".
} 
anunciantes: los anuncios de automóviles los mensajes con letra pequeña siguen siendo la regla general, aunque la velocidad de circulación del scroll en televisión o en internet se haya reducido, y tampoco los consumidores o asociaciones de consumidores denuncian anuncios configurados así). Y, sobre todo, y ésta sería la segunda observación, que no hay que perder de vista la naturaleza de la norma 3, 3 del CCP, ni de la doctrina consolidada en torno a la misma, una doctrina que busca asegurar la franqueza del mensaje y que tiene en la mira, ante todo, la honestidad de la promesa comercial. El Jurado de la Publicidad a la hora de valorar la (in)corrección ética de la publicidad que llega a ser reclamada, resuelve dicha incorrección no porque la omisión de información sobre emisiones o la velocidad e ilegibilidad de la misma pueda afectar al medio ambiente - pues las conductas que incardina en la norma 12 del CCP, respeto del medio ambiente, son otras, como veremos -, sino porque con esa omisión se afecta a la franqueza del mensaje, a la honestidad de la promesa comercial.

\subsection{La laxitud en el control de la "publicidad verde engañosa" cuando no se afecta a la promesa comercial.}

La "publicidad verde engañosa" es, con todo, la más reclamada. El motivo más recurrente en las reclamaciones que se plantean ante el Jurado de la Publicidad - y que éste suele estimar - tiene que ver con la (no) veracidad de las alegaciones medioambientales en los anuncios de automóviles. Así, en una serie de resoluciones, el Jurado ha estimado que se había vulnerado la norma 11 del Código de Autorregulación sobre Argumentos Ambientales, por ejemplo, por no especificar las características del motor que pudieran permitir la atribución del calificativo "ecológico" 47 , o por no acompañar a tal alegación de algún tipo de acotación, en el sentido y en la forma a las que se refieren la norma 11 del Código mencionado ${ }^{48}$. Y ello porque, según estipula dicho Código, las alegaciones supuestamente ecológicas, deben ir acompañadas de algún tipo de aclaración y la argumentación debe ir más allá de las emisiones de $\mathrm{CO}_{2}$, puesto que el Real Decreto 837/2002, al que aludimos más arriba, ya obliga a que las compañías las incluyan en sus anuncios.

Pero la actuación del Jurado de la Publicidad en otros casos no ha sido tan loable. Particularmente en relación a anuncios publicitarios de coches híbridos con alegaciones en que se evocaban - aunque no se hiciera una comparación expresa - características distintivas de los vehículos eléctricos (cuya publicidad es especialmente intensa ahora), como el poseer baterías autorrecargables ${ }^{49}$. El Jurado de la Publicidad considera que las empresas anunciantes no están haciendo alegaciones objetivas contrarias al principio de veracidad sino juicios estimativos que expresan la opinión del anunciante sobre varias características subjetivas que no son susceptibles de ser verificadas objetivamente ${ }^{50}$, y completa este argumento haciendo

\footnotetext{
${ }^{47}$ Cabe citar, por ejemplo, la Resolución de la Sección Sexta del Jurado de 26 de mayo de 2012, asociación Amigos de la Tierra vs. Honda Automóviles España, S.A., "Honda Accord", Fundamento deontológico $2^{\circ}$ por la alegación "motor ecológico $156 \mathrm{CV}(115 \mathrm{~kW})$ ", pues no se especificaba por qué era verde dicho motor. Pero a pesar de la citada Resolución del Jurado, desde la central de la marca seguían insistiendo en la licitud de la utilización del adjetivo "ecológico" para referirse al motor del Accord, puesto que consideraban que era menos contaminante que otras marcas y modelos de la competencia (vid. MUÑOZ, A. (2011). "Primeros anuncios "condenados" por publicidad verde engañosa", El País, 7/10//2011 [En línea]: https://elpais.com/sociedad/2011/10/06/actualidad/1317852013_850215.html

${ }^{48} \mathrm{Vid}$. las Resoluciones de la Sección Primera del Jurado, de 15 de septiembre de 2011, y del Pleno, de 13 de octubre, Amigos de la Tierra vs. Kia Motors Ibérica, S.L., "Kia Picanto".

${ }^{49}$ Puede leerse la Resolución de la Sección Primera del Jurado de Autocontrol de 26 de febrero de 2018, Particular vs. Toyota España, S. L.U., “Toyota Híbrido. Prensa”, a propósito de la reclamación presentada por un particular contra una publicidad de "Toyota Híbrido" en el que se insistía en las baterías autorrecargables, y no así en otras características de los híbridos.

${ }^{50}$ En el caso en cuestión se trataba de las alegaciones de que los vehículos híbridos Toyota, debido a que son automáticos, son prácticos, versátiles y silenciosos, así como las alegaciones "En definitiva, poner un granito de
} 
una remisión al criterio del consumidor medio, normalmente informado y razonablemente atento y perspicaz (pauta interpretativa consolidada en la doctrina del Jurado de la Publicidad), en el sentido de que un consumidor con estas características entenderá que las citadas alegaciones responden a la opinión de la empresa automovilística sobre las bondades de su producto y no a características del mismo, y también entenderá, a juicio del Jurado, que las menciones sobre reducción de emisiones o minimización de las pérdidas de energía son consecuencia de comparar los vehículos híbridos con los convencionales y no con los híbridos.

Argumentos estos, los del Jurado de la Publicidad, que nos parecen criticables: los juicios estimativos que realizan los anunciantes y que, según el Jurado, tienen que ver con características subjetivas no susceptibles de ser verificadas objetivamente también pueden inducir a confusión a un/a consumidor/a medio normalmente informado y razonablemente atento y perspicaz. Y, por otra parte, un/a consumidor/a medio normalmente informado y razonablemente atento y perspicaz no necesariamente puede entender que la comparación se está realizando con los coches convencionales cuando las características que se atribuyen a los híbridos son las típicas de los coches eléctricos.

La laxitud del Jurado de la Publicidad al valorar las alegaciones sobre características distintivas de los vehículos eléctricos contrasta, ciertamente, con la rigurosidad con que procede cuando las alegaciones medioambientales afectan a la confianza que debe existir entre los distintos agentes en el mercado, así, cuando estima que sí constituyen "publicidad verde engañosa" determinadas alegaciones como las relativas al ahorro y la eficacia de los vehículos híbridos Toyota que están hechas en tono excluyente, cuando el anunciante no se encuentra en condiciones de acreditar la veracidad y exactitud de la posición de preeminencia alegada ${ }^{51}$. Con lo cual, creemos, se pone de manifiesto que en su labor de supervisión de las normas (deontológicas) sobre "publicidad verde engañosa", el parámetro que tiene más claro son los intereses de las empresas anunciantes competidoras, y no precisamente el respeto del medio ambiente.

\subsection{La utilización de criterios meramente formales para determinar si la publicidad incita 0 alienta comportamientos que perjudican el medio ambiente.}

Más difícil aún resulta determinar si la publicidad de automóviles incita o alienta comportamientos que perjudiquen el medio ambiente, que es lo que la norma 12 del CCP señala como conducta incorrecta. Esta norma, que es g enérica y abstracta, ha sido precisada por el Jurado de la Publicidad y por la doctrina, de manera que se entiende que la misma prohíbe: 1) incitar, directa o indirectamente, a causar daño al medio ambiente, 2) representar sin reproche o como aceptables y justificadas, conductas que dañan al medio ambiente, 3) presentar de modo negativo o mofarse de conductas que favorezcan el cuidado del medio ambiente ${ }^{52}$.

Ahora bien, aparte de que con esta interpretación de la norma se habría reducido a estas tres categorías de comunicaciones comerciales la diversidad de las malas prácticas en la

\footnotetext{
arena para crear una sociedad más habitable" y "La tecnología híbrida de Toyota ha revolucionado la movilidad, pues permite entre otras cosas que la transición de parado a movimiento sea lo más suave posible". Según el Jurado de la Publicidad, en la medida en que no se percibirán como características objetivas, no cabe apreciar que las mismas resulten contrarias al principio de veracidad consagrado en la norma 14 del Código de Autocontrol (Resolución de la Sección Primera del Jurado de Autocontrol de 26 de febrero de 2018, Particular vs. Toyota España, S. L.U., “Toyota Híbrido. Prensa”, pp. 6-7).

${ }^{51}$ Vid. la Resolución de la Sección Primera del Jurado de 26 de febrero de 2018, Particular vs. Toyota España, S. L.U., "Toyota Híbrido. Prensa", ya comentada.

${ }^{52}$ MEGÍAS QUIRÓS, J. J. Y CABRERA CARO, L. (2013), Ética y Derecho en la Publicidad, op. cit., pp. 157158.
} 
publicidad de automóviles, hay que decir que no es fácil establecer si los anuncios publicitarios encajan en cada uno de los tres supuestos previstos y, por tanto, determinar si se ha incumplido la norma 12 del CCP, a juzgar por las resoluciones del Jurado de la Publicidad.

Incitar, directa o indirectamente, a causar daño al medio ambiente en los anuncios publicitarios es una conducta incorrecta que vulnera la norma 12 del CCP y el Jurado de la Publicidad ha precisado que "incitar" a causar un daño al medio ambiente sería hacer un llamamiento directo o indirecto a la reproducción de la conducta, y que deben darse dos requisitos simultáneos para estimar que el anuncio es incorrecto: a) que se muestre una conducta claramente irresponsable, y b) que se aliente, sin ninguna duda, a la reproducción de esa conducta irresponsable ${ }^{53}$.

No obstante estas precisiones, han sido pocos los anuncios publicitarios denunciados por la ciudadanía como incitadores a conductas que causan daño al medio ambiente, aunque en una gran mayoría de anuncios que se emiten en televisión y en internet, se utilizan distintos recursos estéticos (imágenes oscuras y de carácter fuerte, música rock o de percusión fuerte y sonidos de rugidos de motor), para transmitir potencia, o se representan conductas como el derrape en todo tipo de espacios naturales (desierto, nieve, agua, caminos de tierra, ríos...) ${ }^{54}$. Anuncios que en realidad lindarían con los supuestos prohibidos por la Ley sobre Tráfico, Circulación de Vehículos a Motor y de Seguridad Vial, por incitar a la velocidad excesiva o a la conducción temeraria, y que ponen en peligro, además de la vida, que es lo que aspira a proteger dicha Ley ${ }^{55}$, el medio ambiente.

Por su parte, el Jurado de la Publicidad, más bien se ha limitado a valorar como anuncios publicitarios que incitan a comportamientos que dañan el medio ambiente anuncios en que se representa, sin reproche o como aceptables y justificadas, conductas que dañan al medio ambiente, como los casos de conducción de un todoterreno por vías rurales o por la playa. Lo cual tampoco significa que el Jurado de la Publicidad sea especialmente sensible respecto a las representaciones de automóviles en (o a través) de espacios naturales. Estos espacios siguen siendo escenarios secundarios en los que se representan conductas poco respetuosas con el medio ambiente y también escenarios principales ${ }^{56}$ - aunque durante el confinamiento a

\footnotetext{
${ }^{53}$ MEGÍAS QUIRÓS, J. J. Y CABRERA CARO, L. (2013), Ética y Derecho en la Publicidad, op. cit., p. 157.

${ }^{54}$ Vid. los anuncios estudiados por Aguilar Olmedo, por ejemplo, los anuncios de BMW X-1 "No temo a nada" y el de "Jeep Renegade 2018” (AGUILAR OLMEDO, A. (2018), El medio ambiente en la publicidad. Análisis desde la ética de las virtudes, op. cit., Anexo) y, por citar otro más reciente, el anuncio de Eclipse Cross de la marca Mitsubishi que se viene emitiendo repetitivamente en televisión en el que una chica conduce a toda velocidad por una carretera, y luego por un camino de tierra hasta finalizar en la playa dando vueltas y acelerando mientras suena la sintonía de "El cochecito leré" - Cross the limits (29/4/2019). Anuncio que puede verse en internet (vid. https://www.youtube.com/watch? $v=\_j Y G o K x m P z E$ [última consulta: 21/10/2020]), y que, por el momento, no nos consta que haya sido reclamado. Y puede citarse también los anuncios de productos diferentes a los automóviles en que las marcas utilizan los espacios naturales como escenario, anuncios en los que se adoptan conductas de conducción agresiva. Por ejemplo, el spot de Chloé (eau de parfum) en el que una joven conduce un coche, deja la carretera para circular por el campo y acaba finalmente dando vueltas y revueltas en una playa, emitido en televisión y también en internet (vid: "Chloé (eau de parfum)", https://www.youtube.com/watch?v=33FdI0GdNP4 [última consulta: 21/10/2020]).

${ }^{55}$ La Ley actualmente vigente (Real Decreto Legislativo 6/2015, de 30 de octubre, por el que se aprueba el texto refundido de la Ley sobre Tráfico, Circulación de Vehículos a Motor y Seguridad Vial) sigue conservando el precepto que figuraba en anteriores versiones de la misma, el artículo 52, cuyo tenor es el siguiente: "Publicidad. Se prohíbe la publicidad en relación con vehículos a motor que ofrezca en su argumentación escrita o verbal, en sus elementos sonoros o en sus imágenes, incitación a la velocidad excesiva, a la conducción temeraria, a situaciones de peligro o cualquier otra circunstancia que suponga una conducta contraria a los principios de esta Ley o cuando dicha publicidad induzca al conductor a una falsa o no justificada sensación de seguridad". La cursiva es nuestra.

${ }^{56}$ NÚÑEZ CANSADO, M.; RODRIGO MARTÍN, L. (2015), “Autorregulación y creatividad publicitaria en el sector del automóvil en España: freno al tren verde”, op. cit., p. 45.
} 
raíz de la crisis del coronavirus se limitara el acceso a espacios exteriores para el rodaje de anuncios automovilísticos ${ }^{57}$-, y de ellos se sigue abusando, a nuestro juicio, para compensar, en el plano estético, la gran carga contaminante que tienen algunos automóviles ${ }^{58}$.

Y, sobre todo, es particularmente criticable el criterio que el Jurado de la Publicidad haya establecido para determinar la corrección o incorrección ética de los anuncios publicitarios en que se contienen representaciones de ese tipo de conductas, el criterio consistente en valorar si los anuncios incluyen o no alegaciones meramente formales tales como "Imágenes rodadas por especialistas en caminos rurales aptos para la circulación" o similares ${ }^{59}$. A nuestro juicio, porque es un criterio meramente formal, porque estas alegaciones, además de que no tienen mucho sentido ${ }^{60}$, no aseguran, por su mera inclusión en los anuncios publicitarios, una protección del medio ambiente ni tampoco alteran la representación de la conducta no respetuosa con el medio ambiente, una representación que puede propiciar la reproducción de esa conducta en quienes visualizan dicha publicidad.

Incluso podría estimarse criticable, desde la óptica del respeto al medio ambiente, el hecho de valorar la corrección o incorrección ética de un anuncio de automóviles en que se utilizan espacios naturales, según que contenga o no alegaciones en que se indique actuar conforme a la legislación vigente. Así, a propósito del anuncio publicitario de un Volvo XC60 estacionado en la playa mientras su ocupante se dedica a surfear, el Jurado de la Publicidad ha precisado que "aunque [el anuncio] sea una creación artística, se halla sujeta, como toda publicidad, a la normativa publicitaria y al resto del ordenamiento jurídico pertinente en el caso concreto" 61 , y, en específico, la Ley 22/1988, de 28 de julio, de Costas, establece, efectivamente, que está prohibido el estacionamiento y la circulación no autorizada de vehículos (art- 33.5). Pero lo

\footnotetext{
57 JUÁREZ, E. (2020), "La original forma de grabar el anuncio de un coche sin salir de casa", La Vanguardia, 26/04/2020. [En línea]:

https://www.lavanguardia.com/motor/videos/20200426/48671889914/honda-civic-sedan-anunciocoronavirus.html

${ }^{58}$ Sobre todo, el SUV (el todoterreno moderno), como puede apreciarse en el anuncio de contenido desarrollado por Land Rover y difundido a través de twitter y periódicos digitales en el que uno de los automóviles de la marca aparece circulando (o "nadando") literalmente, en el mar, abusándose así del mar como recurso estético. Véase: CONTENT FACTORY (2018), "Un SUV Premium para descubrir el mundo", ABC, 17/9/2018 [En línea]: https://www.abc.es/contentfactory/post/2018/08/29/un-suv-premium-para-descubrir-el-fin-del-mundo/; y también: PÉREZ FEITO, C. (2019), ¿Qué es un SUV y por qué triunfan en España?”, $A B C, 16 / 10 / 2019$ [En línea]: https://www.abc.es/contentfactory/post/2017/06/23/que-es-un-suv-y-por-que-triunfa-en-espana/. Cuando se trata del tipo de automóvil que más combustible requiere, el que genera más ruido y más gases de efecto invernadero y gases contaminantes para la salud ECOLOGISTAS EN ACCIÓN (2006), "Plataforma internacional contra los 4x4", 20/10/2006 [En línea]: https://www.ecologistasenaccion.org/6045/plataformainternacional-contra-los-4x4/; ECOLOGISTAS EN ACCIÓN (2019), "Los todoterreno son una nueva amenaza para el clima", op.cit.

${ }^{59}$ Es lo que lo que se desprende de la Resolución de la Sección Primera del Jurado, de 14 de febrero de 2007, Particular vs. Volkswagen-Audi, S.A., "Volkswagen Touareg", en el que el Jurado de la Publicidad precisa que el anuncio (en el que a juicio del particular reclamante se representaba a un vehículo que circulaba brutalmente por la naturaleza destrozando caminos y degradando el lecho del río, compitiendo con un salmón) no era correcto porque "tanto el tamaño de la letra como el tiempo de permanencia en pantalla de la mencionada leyenda (“Imágenes rodadas por especialistas en caminos rurales no aptos para la circulación”) resultaba claramente insuficiente para que el público consumidor pudiera leer su contenido. Vid. el Fundamento deontológico $3^{\circ}$ de la Resolución mencionada.

${ }^{60}$ Como señala Aguilar en su trabajo, "resulta un poco irónico que se tengan que utilizar especialistas para exaltar un producto que será usado por usuarios comunes en carretera. Un coche no se usa para hacer derrapes en caminos de tierra, circuitos de nieve o circuitos de velocidad como vemos en algunos spots" (AGUILAR OLMEDO, A. (2018), El medio ambiente en la publicidad. Análisis desde la ética de las virtudes, op. cit., p. 18).

${ }^{61}$ Resolución de 3 de diciembre de 2015 de la Sección Quinta del Jurado de Autocontrol, Particular vs. Volvo Car España S.L.U., "VolvoXC60”, II. 4, p. 5.
} 
dicho por el Jurado de la Publicidad también puede ser interpretado en el sentido de que, de respetarse dicha legalidad, o de representar los anuncios publicitarios a coches no estacionados en la playa o de autorizar la circulación de vehículos en espacios naturales, los anuncios son correctos éticamente, cuando desde la óptica del medio ambiente es cuestionable incluso el que desde la legislación se autorice dicha circulación. El hecho de que algún elemento en la publicidad sugiera - es el término que utiliza el Jurado de la Publicidad ${ }^{62}$ - que existe un acceso autorizado a espacios naturales, en nuestra opinión, no debería convertirse en un criterio para valorar la corrección ética (deontológica, más precisamente) de la publicidad. Fundamentalmente porque - y en ello queremos insistir especialmente - lo dispuesto en la ley es, en definitiva, una obligación legal y lo legal, como expresa Cossette, no necesariamente es lo ético ${ }^{63}$.

Finalmente, atenta contra la norma 12 del CCP presentar de modo negativo o mofarse de conductas que favorezcan el cuidado del medio ambiente. En este sentido, se han considerado incorrectos desde el punto de vista deontológico anuncios en que hace una burla del transporte público o del metro, de campañas de sensibilización ambiental o de propuestas de ahorro energético, como fue el caso de la publicidad de la aseguradora Zurich con motivo del "Día sin coche", al publicitarse un anuncio en el que se decía "¿Un día sin coche? Ni pensarlo", o el anuncio de Nissan Juke, en el que aparecían imágenes del metro con una rata como pasajera ${ }^{64}$.

Pero en algunos casos el Jurado de la Publicidad no ha percibido - o no ha resuelto - que se estaba haciendo mofa de conductas a favor del cuidado del medio ambiente. El caso de la reclamación que se presentó contra la publicidad del Fiat 500 por incluir la alegación "Desengáñate. Compartir asiento con desconocidos sólo es romántico en las canciones", puede ser ilustrativo a este respecto. La Asociación de Usuarios de la Comunicación (usualmente conocida por sus siglas, AUC) valoró que el mensaje no destacaba las ventajas del vehículo, sino que basaba su estrategia en denigrar la oferta del transporte público. El Jurado de la Publicidad, en cambio, estimó que se trataba de una interpretación subjetiva, pues en ningún momento la publicidad hacía referencia negativa explícita ni implícita al transporte público, ni a sus características ni a sus prestaciones ${ }^{65}$. Una estimación - la del Jurado bastante benévolo (o, mejor dicho, laxo). En el anuncio en cuestión no se hacía ninguna alusión al transporte público como tal, ciertamente, pero de la interpretación del anuncio en su conjunto - conforme a la norma 3 del CCP, respecto a la cual el Jurado de la Publicidad ya tiene doctrina consolidada - se podía desprender que se estaba refiriendo al transporte público y dañando su imagen, motivo por el cual el anuncio debió ser declarado incorrecto y, en consecuencia, retirarse de los medios.

\section{A modo de conclusión.}

De la publicidad comercial puede decirse que, en general, es más instrumental a la sociedad de consumo que a la protección del medio ambiente, y esto sería más cierto en el caso de la publicidad de automóviles, "el objeto de consumo más anunciado del mundo" y, al mismo tiempo, uno de los más contaminantes. Pese a ello, son más bien escasas - además de

\footnotetext{
${ }^{62}$ Es lo que viene a decir el Jurado, así en la Resolución de 3 de diciembre de 2015 de la Sección Quinta del Jurado de Autocontrol, Particular vs. Volvo Car España S.L.U., "VolvoXC60": que "no existe elemento alguno en la publicidad que exprese o al menos sugiera que el lugar donde se ha estacionado el vehículo está habilitado para esos usos o que el vehículo está autorizado para el acceso y estacionamiento en el lugar reflejado en la publicidad" (Fundamento deontológico 3, $4^{\circ}$ párrafo).

${ }^{63}$ COSSETTE, C. (2009), Éthique et publicité. Laval: Presses de 1’Université de Laval, p. 49.

${ }^{64}$ MEGÍAS QUIRÓS, J. J. Y CABRERA CARO, L. (2013). Ética y Derecho en la Publicidad, op. cit., p. 158.

${ }^{65}$ Vid. la Resolución de la Sección Segunda del Jurado de Autocontrol de 30 de mayo de 2013, AUC vs. Fiat Group Automobiles Spain, S.L., "Fiat 500 L", Fundamentos deontológicos $2^{\circ}$ y $3^{\circ}$.
} 
frecuentemente incumplidas - las obligaciones legales impuestas a las empresas fabricantes y/o anunciantes de automóviles. Obligaciones que, además, están pensadas más bien para proteger a las personas en tanto consumidores más que al medio ambiente, como es la de informar sobre el consumo de combustible y la emisión de $\mathrm{CO}_{2}$, al comercializar turismos nuevos.

Son sobre todo normas (deontológicas) establecidas por las propias empresas anunciantes (normas a las que éstas voluntariamente deciden someterse o no) las que controlan la publicidad de automóviles, en concreto, el Código de Conducta Publicitaria y en el Código de Autorregulación sobre Argumentos Ambientales en Comunicaciones Comerciales. En estos códigos deontológicos se contiene expresamente el principio de respeto al medio ambiente. Sin embargo, la labor de supervisión del respeto de este principio que realiza el órgano del sistema de autorregulación publicitaria, el Jurado de la Publicidad, es discutible. Básicamente porque en esa labor de supervisión tiene en cuenta ante todo que las alegaciones sobre consumo de combustible y emisiones de $\mathrm{CO}_{2}$ a que obliga la legislación a los fabricantes y/o anunciantes no afecten a la honestidad de la promesa comercial, e igualmente ocurre en el caso de las alegaciones medioambientales, respecto a las cuales es más riguroso cuando las mismas afectan a la confianza que debe existir entre los agentes del mercado.

Asimismo, pueden apreciarse las especiales dificultades - o reticencias - del Jurado de la Publicidad a la hora de verificar si los anuncios publicitarios incitan a un comportamiento no respetuoso con el medio ambiente, representan conductas perjudiciales para el medio ambiente, o hacen mofa de conductas que favorecen el cuidado del medio ambiente. De hecho, para determinar la corrección ética o no de los anuncios publicitarios parece prestar más atención a los aspectos formales de los mensajes publicitarios medioambientales (por ejemplo, vigilando que incluyan las advertencias exigidas deontológicamente en caso de utilizarse espacios naturales, o que se cumplan los buenos usos mercantiles), que a si los anuncios en realidad respetan o promueven actitudes de respeto del medio ambiente. Todo lo cual creemos que demuestra las limitaciones que tiene el sistema de autorregulación de la publicidad en lo que al respeto del medio ambiente se refiere y, en consecuencia, la necesidad de regular de forma más amplia dicha publicidad y de establecer límites a la misma. 
6. Bibliografía y materiales de referencia.

\subsection{Libros, artículos de revistas, trabajos académicos.}

- AGUILAR OLMEDO, A. (2018), "El medio ambiente en la publicidad. Análisis desde la ética de las virtudes". Trabajo de Fin de Grado (inédito), curso académico 2018-19, Jerez de la Frontera: Facultad de Ciencias Sociales y de la Comunicación, Universidad de Cádiz.

- ANDALUZ, J. Y ESTEBAN, A. (2015), "Emisiones en España: alimentación, transporte", Ecologista, 86, pp. 25-26.

- BRAU, L. (2018), "La ciudad del coche". Biblio3W. Revista Bibliográfica de Geografía y Ciencias Sociales, vol. XXIII, $n^{\circ}$ 1235, Barcelona: Universidad de Barcelona, 5 de mayo de 2018, pp. 1-27. [En línea]: http://www.ub.edu/geocrit/b3w1235.pdf

- COSSETTE, C. (2009), "Éthique et publicité". Laval: Presses de l'Université de Laval.

- DONOVAN, R.J., FIELDER, L.J., OUSCHAN, R., EWING, M., "Self-regulation of motor vehicle advertising: Is it working in Australia?", Accident Analysis \& Prevention, vol. 43, Issue 3, May 2011, pp. 631-636.

- DONOVAN, R.J., FIELDER, L.J., EWING, M.; OUSCHAN, R., "Regulation of motor vehicle advertising: Toward a framework for compliance research", Journal of the Australasian College of Road Safety, vol. 22, Issue 4, Dec 2011, pp. 73-81.

- GALEANO, E. (sin fecha), "La religión del automóvil”. Servicios de Comunicación Intercultural. [En línea]: https://www.servindi.org/actualidad/1427

- GORZ, A. (1973), “La ideología social del automóvil”, Letras libres, 11, Núm. 132, 2009, pp. 14-17. [En línea]: https://www.letraslibres.com/mexico-espana/laideologia-social-del-automovil

- HERAS HERNÁNDEZ, F. (2012), “El uso de argumentos ambientales en publicidad. Definiendo líneas rojas, reconociendo buenas prácticas", Boletín Carpeta Informativa del Centro Nacional de Educación Ambiental. CENEAM, O.A. Parques Nacionales, pp. 1-7.

- LÓPEZ PASTOR, A.T., DE ANDRÉS DEL CAMPO, S., Y GONZÁLEZ MARTÍN, R. (2007), "Tratamiento del medio ambiente en la publicidad convencional" (20062007). Resumen de Informe, Ministerio de Medio Ambiente y medio rural y marino, Universidad de Valladolid.

- MARTÍN, E. (1991), "Mercado en punto muerto: A pesar de la recesión, los fabricantes de automóviles de turismo destinaron en 1990 un 12,9\% más a publicidad que en 1989", Anuncios: Semanario de publicidad y marketing, $\mathrm{n}^{\circ}$ 467, 25 de marzo de 1991, pp. 32-33. 
- MARTÍNEZ PISÓN, J. (2004), "Las generaciones de derechos", en BETEGÓN, J., LAPORTA, F.J., PARAMO, J.R., DE Y PRIETO SANCHÍS, L. (Coords,): Constitución y Derechos Fundamentales. Madrid: Centro de Estudios Políticos y Constitucionales, pp. 409-435.

- MARTÍN-SOSA, S., GARCÍA, M. Y GONZÁLEZ, M. (2015/2016), “Engaños de la industria automovilística. Caso Volkswagen: la punta del iceberg de un sistema fraudulento", Ecologista, 87, pp. 32-33.

- MEGÍAS QUIRÓS, J. J. Y CABRERA CARO, L. (2013). "Ética y Derecho en la Publicidad". Granada: Comares,

- NÚÑEZ CANSADO, M.; RODRIGO MARTÍN, L. (2015), "Autorregulación y creatividad publicitaria en el sector del automóvil en España: freno al tren verde", Revista de Comunicación Vivat Academia, septiembre 2015, Año XVIII, no 132, pp. 38-87.

- PEDRÓS PÉREZ, G. (2007), "Hacia una publicidad responsable frente al cambio climático. Borrador para el debate”. Centro Nacional de Educación Ambiental, CENEAM, Oficina Española de Cambio Climático, OECC, pp. 1-28.

- RAMOS FERNÁNDEZ, L.F. (2001), “Autorregulación, mediación y consulta previa, la nueva frontera de la ética publicitaria", Zer: Revista de estudios de comunicación, $\mathrm{n}^{\circ}$ 11, pp.1-11.

- RIECHMANN, J. (2005). "Son necesarios cambios sustantivos", Revista Española de Salud Pública, vol. 79, pp. 129-131.

- RIECHMANN, J. (2008), ¿En qué estamos fallando? Cambio social para ecologizar el mundo", e-book.

- RUIZ PACHECO, C.; CONDE GUERRI, M.E. (2002), "El uso del medio ambiente en la publicidad", Medio Ambiente y Comportamiento Humano, 3 (1), pp. 89-101.

- TAPIA GRANADOS, J.A. (1998), "La reducción del tráfico de automóviles: una política urgente de promoción de la salud", Revista Panamericana de Salud Públical Pan Am J Public Health, 3 (3), pp. 137-151.

\subsection{Artículos de prensa (digital).}

- BERMÚDEZ, J.J. (2009), “La ideología del coche eléctrico”, Canarias Ahora, 14/08/2008.[En línea]:

https://www.eldiario.es/canariasahora/canariasopina/ideologia-coche-

electrico_6_292630774.html

- CONTENT FACTORY (2018), "Un SUV Premium para descubrir el mundo”, $A B C$, 17/9/2018 [En línea]: https://www.abc.es/contentfactory/post/2018/08/29/un-suvpremium-para-descubrir-el-fin-del-mundo/ 
- CHEVALIER, J., "Quand une voiture dans la nature offense le regard du juge", Le Point Automobile, 23/10/2012. [En línea]: https://www.lepoint.fr/automobile/quandune-voiture-dans-la-nature-offense-le-regard-du-juge-23-10-2012-1520221_646.php

- DE MIGUEL, B., PLANELLES, M. (2019), "Bruselas lleva a España ante la justicia por la contaminación en Madrid y Barcelona”, Bruselas/Madrid, El País, 24/07/2019. [En línea]: https://elpais.com/sociedad/2019/07/23/actualidad/1563894873_941133.html

- DOMINGO, M.R., CALLEJA, I.S. (2019), "Almeida inicia la reversión de carriles bici por el de la Gran Vía de Hortaleza", $A B C, 28 / 10 / 2019$ [En línea]: https://www.abc.es/espana/madrid/abci-almeida-inicia-reversion-carriles-bici-granhortaleza-201910280125_noticia.html

- EFE (2019). “Greta Thunberg en Roma: "Los líderes me felicitan, pero no actúan por el clima"”, $A B C, 18 / 4 / 2019$. [En línea]:

http://www.abc.com.py/internacionales/greta-thunberg-los-lideres-me-felicitan-perono-actuan-por-el-clima-1806502.html

- ELCACHO, J. (2020), "La OMS reitera que la contaminación del aire empeora el pronóstico de la Covid-19”, La Vanguardia, 07/09/2020. [En línea]: https://www.lavanguardia.com/natural/contaminacion/20200907/483347888356/laoms-reitera-que-la-contaminacion-del-aire-empeora-el-pronostico-de-la-covid19.html

- FERNÁNDEZ, S. (2020), “Automoción despierta su publicidad para luchar contra la crisis del Covid-19", 18/08/2020. [En línea]: https://www.elpublicista.es/reportajes/automocion-despierta-publicidad-para-lucharcontra-crisis-covid

- JUÁREZ, E. (2020), "La original forma de grabar el anuncio de un coche sin salir de casa”, La Vanguardia, 26/04/2020. [En línea]: https://www.lavanguardia.com/motor/videos/20200426/48671889914/honda-civicsedan-anuncio-coronavirus.html

- MUÑOZ, A. (2011), "Primeros anuncios "condenados" por publicidad verde engañosa”. El País, 7/10/2011. [En línea]: https://elpais.com/sociedad/2011/10/06/actualidad/1317852013_850215.html

- PÉREZ FEITO, C. (2019), “QQué es un SUV y por qué triunfan en España?”. $A B C$, 16/10/2019. [En línea]: https://www.abc.es/contentfactory/post/2017/06/23/que-esun-suv-y-por-que-triunfa-en-espana/

- REDACCIÓN DE LA VANGUARDIA. (2020): "Ecologistas defiende que el coche eléctrico genera "un gran impacto ambiental", La Vanguardia, 28/02/2020. [En línea]: https://www.lavanguardia.com/vida/20200228/473824252974/ecologistasdefiende-que-coche-electrico-genera-un-gran-impacto-ambiental.html 
6.3. Documentos de asociaciones de publicistas, consumidores y ecologistas:

- ASOCIACIÓN GLOBALÍZATE (2005), “Automóviles y publicidad” [En línea]: http://www.globalizate.org

- AUtOCONTROL. (1996), “Código de Conducta Publicitaria" [En línea]: https://www.autocontrol.es/wp-content/uploads/2017/12/codigo-de-conductapublicitaria-autocontrol.pdf

- ECOLOGISTAS EN ACCIÓN. (2006), "Plataforma internacional contra los 4x4", 20/10/2006. [En línea]: https://www.ecologistasenaccion.org/6045/plataformainternacional-contra-los-4x4/

- ECOLOGISTAS EN ACCIÓN. (2009), “Coche ecológico/emisiones de $\mathrm{CO}_{2}$ de los vehículos convencionales e híbridos”, 1/12/2009. [En línea]: https://www.ecologistasenaccion.org/16233/2-emisiones-de-co2-de-los-vehiculosconvencionales-e-hibridos/

- ECOLOGISTAS EN ACCIÓN (2019), “Los todoterreno son una nueva amenaza para el clima", 11/6/2019. [En línea]:

https://www.ecologistasenaccion.org/122410/los-todoterreno-son-una-nuevaamenaza-para-el-clima/

- FERNÁNDEZ CARRASCO, A. (2020), “Así ha bajado la contaminación durante el estado de alarma por el coronavirus", 19/03/2020. [En línea]: https://es.greenpeace.org/es/noticias/asi-ha-bajado-la-contaminacion-durante-elestado-de-alarma-por-el-coronavirus/

- LASHERAS, J. (2016), "La prohibición de la publicidad contraria al medio ambiente", Observatorio Jurídico de la Publicidad, 12/6/2016 [En línea]: http://observatoriojuridicodelapublicidad.com/la-prohibicion-de-la-publicidadcontraria-al-medio-ambiente/

- REDACCIÓN DE NATIONAL GEOGRAPHIC ESPAÑA, (2020), "El coronavirus reduce la contaminación del aire”, National Geographic España, 24/04/2020. [En línea]: https://www.nationalgeographic.com.es/ciencia/coronavirus-reducecontanimacion-aire-europa_15370

- UNIÓN DE CONSUMIDORES DE ESPAÑA, UCE (ed.). (2008), Informe publicidad medio ambiente.

\subsection{Resoluciones del Jurado de la Publicidad:}

- Resolución de la Sección Primera del Jurado de Autocontrol, de 14 de febrero de 2007, Particular vs. Volkswagen-Audi, S.A., "Volkswagen Touareg".

- Resolución de la Sección Primera del Jurado de Autocontrol, de 2 de junio de 2011, AUC vs. Honda Automóviles España, S.A., "Honda Civic". 
- Resolución de la Sección Quinta del Jurado de Autocontrol, de 30 de junio de 2011, AUC vs. General Motors España, S.L., "Opel Corsa".

- Resolución de la Sección Primera del Jurado de Autocontrol, de 30 de julio de 2011, AUC vs Suzuki Motor España, S.A.U.).

- Resolución de la Sección Primera del Jurado de Autocontrol, de 15 de septiembre de 2011, Amigos de la Tierra vs. Kia Motors Ibérica, S.L., "Kia Picanto".

- Resolución del Pleno del Jurado de Autocontrol, de 13 de octubre de 2011, Amigos de la Tierra vs. Kia Motors Ibérica, S.L., "Kia Picanto".

- Resolución de la Sección Sexta del Jurado de Autocontrol, de 16 de febrero de 2012, Amigos de la Tierra vs. Hyundai Motor España, S.L.U., "Hyundai IX35".

- Resolución de la Sección Sexta del Jurado de Autocontrol, de 26 de mayo de 2012, asociación Amigos de la Tierra vs. Honda Automóviles España, S.A., "Honda Accord".

- Resolución de la Sección Segunda del Jurado de Autocontrol, de 30 de mayo de 2013, AUC vs. Fiat Group Automobiles Spain, S.L., "Fiat 500 L".

- Resolución de la Sección Quinta del Jurado de Autocontrol, de 3 de diciembre de 2015, Particular vs. Volvo Car España S.L.U., "Volvo XC60".

- Resolución de la Sección Primera del Jurado de Autocontrol, de 26 de febrero de 2018, Particular vs. Toyota España, S. L.U., "Toyota Híbrido. Prensa". 